УДК 81

DOI: 10.33184/YVDK-2021-04-30.10

Б.Т. Мухтаров (стажер-исследователь БашГУ, г. Уфа)

\title{
ТЕХНИЧЕСКИЕ ОСОБЕННОСТИ СУБТИТРОВАНИЯ
}

B cтатье рассматривается перевод при помощи субтитрирования, а также технические особенности данного вида перевода. Соблюдение описанных требований является одним из важных отличий профессионального перевода от любительского.

Ключевые слова: субтитры; субтитрирование; аудиовизуальный перевод; кинематограф

The article deals with the subtitling and its technical aspects. Adherence to these rules is one of the key differences between a professional translation and an amateur one.

Key Words: subtitles; subtitling; audiovisual translation; cinematography

Субтитрование является первым и старейшим способом перевода аудиовизуального текста. Впервые появившись еще в 1903 году, в виде интертитров - текста, появляющегося между сценами и объяснявшего их содержание, описывающего диалоги, смену времени и т.д. [https:/ru.wikipedia.org/wiki/Титры], данная техника перевода получила болышую популярность и распространение. В наше время, несмотря на то, что абсолютнюе большинство известных фильмов и сериалов дублируются на языки местных рынков, многие люди предпочитают субтитры, так как это позволяет сльшать оригинальную речь актёров, а также, может быть использовано в образовательных целях.

Актуальность данной работы обусловлена широким растространением субтитрированного перевода аудиовизуальных текстов и их важной ролью в распространении массовой культуры. Стоит отметить, что субтитры часто выполняются непрофессионалами, с нарушением технических норм, что может привести кзатруднению восприятия текста зрителем.

Цель исследования - определить основные технические требования к субтитрам. 
Субтитры должны иметь строго определенный внешний вид располагаться на экране не слишком высоко, чтобы не загораживать собой изображение, и неслишком низко, иначе зритель, перенося взгляд на субтитры, не будет видеть, что в это время происходит на экране (или вообе рискует не заметить появления новой строки). Вертикальный отступ должен составлять 1/12 высоты экрана. Субтитры должны располагаться в нижней части экрана. Расположение вверху допустимо, если в кадре одновременно звучат два независимых потока речи, при этом, вверху должен быть имеющий менышее значение. Отступ слева и справа должен быть равен 1/12 шириныэкрана.

Субтитры должны иметь не болыше двух строк. Большее количество строк будет загораживать изображение

Выравнивание производится по центру экрана. При разговоре двух и более персонажей, их речь Должна быть оформлена как диалог, со знаком « начале реплики каждого из них. При этом допускается выравнивание текста по левому краю.

Количество символов в одной строчке не должно превышать 40, однако, в русском языке, в связи с, примерно, в полтора раза болышей длиной предложения, по сравнению с европейскими языками, допустимо умещать 45-50 символов в однустроку.

Для субтитров используются максимально простые для восприятия шрифты, такие как Arial и Trebuchet. Шрифты с одинаковой длиной символов, например, Times New Roman, Courier New и т.д. не рекомендуется использовать. Размер шрифта обычно равен 1/12 высоты экранаили меныше.

Цвег для субтитров должен быт белым, но не ярким, а чугь сероватым. Для того, чтобы суб̆итры не сливались с белым или ярким фоном, они должны иметь чёрную окантовку.

Количество знаков в секунду для детских фильмов и передач - 13 знаков в секунду, для взросльх - 17знаков в секунду.

Максимальная диина строки суб̆титров-39 знаков в строке.

Однострочные субтитры, содержашие до 50 символов, появляются на экранене менее, чем на 1.5 секунды, и не более, чем на 3.5 секунды.

Субтитры, содержащие две строки, должны появляться на экран не менее, чем на 3.5 секунды и не более, чем на 6 секунд. Зритель не успеет прочитать субтитр менее, чем за 3.5 секунды, а при нахождении его на экране более 6 секунд, он будет отвлекать на себя внимание, в результате чего, зритель может ошибочно начать читать его заново. Причины выбора интервалов одинаковые для однострочных и двустрочных субтитров. 
Продолжительность субтитра в одно слово, независимо от его простоты и длины, должно составлять как минимум 1,5 секунды, иначе зритель может его незаметить.

Субтитр должен появиться на экране, спустя 0,25 секунды после начала соответствующей реплики. Так зритель успеет понять, который персонаж начал говорить, и перенести взгляд вниз экрана, где появятся субтитры. В случае, если текст довольно длинный, а персонаж быстро произнёс свою реплику, субтитр следует оставить на экране, но неболее, чем на 2 секунды после окончания речи.

Интервал появления субтитров должен быть неменее 0.25 секунды. При такоминтервалезритель успевает заметить переменутекста субтитров.

При быстрой смене кадра на изображающий друго место, не рекомендуется оставлять на экране субтитр относящийся к предыдущему кадру. В случае плавной смены кадра, либо если при смене кадра камера показывает, то же самюе место действия, субтитр можно оставить неизменным.

Точку необходимо ставить в конце предпожения, даже если оно занимает болыше двух строк.

Тире используются для обозначения диалога: в начале каждой строки стоит тире, а затем через пробел предложение с заглавной буквы. Дефис используется согласно правилам русского языка, также, как и в остальных случаях тире.

Вопросительные и восклицательные знаки ставятся в конще предложения вместо точки. Несколько восклицательных/ вопросительных знаков подряд ставить нерекомендуется.

Кавычки, двоеточия, запятые, точки с запятой используются также, каки в обычном письме.

В квадратных скобках используются для выделения примечаний переводчика.

Курсивом обозначены слова, которые произносятся кем-то, кого сейчас нет в том месте, где разворачивается действие: мысли персонажа, закадровый текст, голос из телефонной трубки и т.д. Кавычками с курсивом обозначаются теле-и радиотрансляции, то есть, когда информация передаётся сразу нескольким приёмникам, телефонная связь в эту категорию не попадает. Так же выделяется текст песен. Надписи отмечаются в кавычках, но без курсива.

Высоким регистром обозначаются только аббревиатуры. Жирным и подчёркнупым текстом пользоваться нельзя [Требования к переводу с помощью субтитров [Электронный ресурc] URL: hitp//kaijukeizer.blogspot.ru/p/blogpage_28.html]. 
Текст на экране.

Повествовательные заголовки (Forced Narrative) для текста на экране должны включаться только в том случае, если они имеют отношениек сюжету.

Продолжительность суббитров повествовательных заголовков должна соответствовать продолжительности текста наэкране

Если повествовательные заголовки, включены в диалог, или иным образомпоявляютсяна экране, их включать в суб̆итры ненужно.

За исключением длинного текста (например, пролога и эпилога), повествовательныезаголовки пишугся в верхнем регистре

Нельзя совмещать субтитр для экранного текста и субтитр диалога в одном и томжесубтитре.

Если нельзя избежать прерывания диалога субтитрами дпя экранного текста, необходимо использовать многоточие в конце предложения, которое предшествуег ему, и в начале следующего предпожения.

Иностранные диалоги должны переводиться только если зритель должен их понимать(Были субтитрированы и в оригинале).

В случае если зритель должен понимать иностранные слова и фразы они должны быпь переведены. В случае если они не были пояснены в оригинале их следует оставить неизменными и написаны курсивом.

Таким образом можно составить следующие основные технические требования к субтитрам - субтитры должны располагаться внизу экрана, иметь простой для восприятия шрифт. При написании субтитров необходимо соблюдать время появления строчки на экране - 0.25 секунды после начала реплики, рекомендуемое количество символов в строке - 39 символов и время нахождения субтитра на экране (не должно превышать 2 секунды после окончания речи).

\section{ЛИТЕРАТУРА}

1. https://ru.wikipedia.org/wiki/Титры

2. hittp//kaijukeizer.blogspot.ru/p/blog-page_28.html

(C) Мухтаров Б.Т., 2021 г. 